\title{
In silico analysis of drought responsive transposons and transcription factors in Solanum tuberosum L.
}

\section{Patatesde (Solanum tuberosum L.) kurağa tepki veren transpozonların ve transkripsiyon faktörlerin in siliko analizi}

\author{
Ebru DERELLi TÜFEKÇi ${ }^{1 *}$ iD, Behcet iNAL ${ }^{2}$ (D) \\ ${ }^{* 1}$ Cankiri Karatekin University, Yapraklı Vocational High School, Department of Field Crops, Cankiri, Turkey \\ ${ }^{2}$ Siirt University, Faculty of Agriculture, Department of Agricultural Biotechnology, Siirt, Turkey
}

To cite this article:

Derelli Tüfekçi, E. \& İnal, B. (2019). In silico analysis of drought responsive transposons and transcription factors in Solanum tuberosum L.. Harran Tarım ve Gıda Bilimleri Dergisi, 23(2):189195.

DOI:10.29050/harranziraat.439682

Address for Correspondence: Ebru DERELLI TÜFEKÇi e-mail:

ebru.derelli@gmail.com

Received Date:

02.07.2018

Accepted Date:

30.11.2018

(c) Copyright 2018 by Harran University Faculty of Agriculture. Available on-line at www.dergipark.gov.tr/harranziraat

This work is licensed under Creative Common Attribution-Non Con

\section{ABSTRACT}

Potato (Solanum tuberosum L.) is the most important non-grainfood crop and is essential for global food security. Drought is one of the major abiotic stress factors resulting in huge yield loss in the production of crops and similarly, it negativelly affects the tuberization, tuber yield and tuber quality of potato. Transposable elements (TES) account for a large portion of the genome in many eukaryotic species. Several studies have identified the molecular mechanism that cause the activation of TEs under stress. Stresses and environmental challenges, in particular, are known to alter the expression or stimulate the transposition of mobile elements in plants. Transcription of these stress-responsive genes is largely controlled by transcription factors (TFs). A number of transcription factors playing an essential role in drought tolerance of plants have been identified in the past few years. In this work, a subset of drought responsive TE families and TFs in potato at tuber bulking stage was defined, based on genome-wide transposon homology and annotation. Our results indicated that, the read numbers for TE subfamilies yielded different distributions between DNA and RNA transposons. In addition, many TFs such as bHLH, WRKY, NAC, AP2/ERF may have important functions in regulation of drought tolerance in potato. Identification of TES and TFs which are taking part in stress can offer useful information for functional genomics and designing novel breeding strategies for developing stress tolerant plants.

Key Words: Drought, Potato, Transcription, Transposon, Transcription factor

\section{öz}

Patates (Solanum tuberosum L.) tahıl grubundan olmayan önemli bir kültür bitkisidir ve küresel gıda güvenliği açısından büyük bir öneme sahiptir. Kuraklık, tarımsal üretimde büyük verim kayıplarına neden olan başlıca abiyotik stres faktörlerinden biridir ve patatesde yumru oluşumu, yumru verimi ve yumruların kalitesini olumsuz yönde etkilemektedir. Birçok ökaryotik türdeki genomun büyük bir bölümünü hareketli elementler oluşturmaktadır. Transpozon elementlerin (TE) stres altında nasıl aktive olduklarının moleküler mekanızması birçok çalışmada tanımlamıştır. Stres ve çevresel zorlukların, özellikle bitkilerde hareketli elementlerin ekspresyonunu veya transpozisyonunu uyardığı bilinmektedir. Strese tepki veren bu genlerin transkripsiyonu büyük ölçüde transkripsiyon faktörleri tarafından kontrol edilmektedir. Son yıllarda, bitkilerin kurağa tepkilerinin düzenlenmesinde önemli role sahip bazı transkripsiyon faktörleri belirlenmiştir. Bu çalışmada, transkripsiyon homolojisi ve anotasyon yaklaşımı kullanılarak yumru büyütme dönemindeki patateste kuraklığa tepki veren hareketli elementler ve transkripsiyon faktörü aileleri tanımlanmıştır. Sonuçlarımız, hareketli elementlerin alt aileleri için okuma sayılarının DNA ve RNA transpozonları arasında farklı dağılımlar sağladığını ve bHLH, WRKY, NAC, AP2/ERF transkripsiyon faktörlerini kodlayan çok sayıda genin, kuraklık stresine tepkinin düzenlenmesinde önemli işlevlere sahip olabileceğini göstermiştir. Strese tepkide yer alan hareketli elementlerin ve transkripsiyon faktörlerin 
tanımlanması ve bunların beraber değerlendirilmesi, işlevsel genomik çalışmaları ve strese dirençli bitkilerin geliştirilmesinde yeni ıslah stratejilerinin tasarlanması için yararlı bilgiler sağlayabilir.

Anahtar Kelimeler: Kuraklık, Patates, Transkripsiyon, Transpozon, Transkripsiyon faktör

\section{Introduction}

Potato (Solanum tuberosum L.) ranks as the thirth most predominant non-grain food crop in the world behind wheat and rice (FAOSTAT, 2017). However, cultivated potato is an autotetraploid $(2 \mathrm{n}=48)$ which complicates genetic studies as well as breeding efforts to improve important traits such as disease resistance, processing quality and nutritional importance (Felcher et al., 2012). In the potato, tuber accumulates high levels of starch. Additionally to starch, tubers also contain small amounts of sucrose, glucose and fructose. The quantitiy of starch and sugars present in tubers depend on the genetic and environmental factors (Draffehn et al., 2010).

Drought is one of the major abiotic stress factors due to the limited water resources resulting in huge yield loss in the production of crops and causing damage in reproductive plant development (Wu et al., 2014). To cope with the challenging aspects of drought, plants use several mechanisms and produce response at physiological and molecular levels (Tripathi et al., 2014). One of them is transposable elements (TEs), causes mutant alleles by altering the reading frame or splicing profile, frequently adversely influencing gene function (Lisch, 2013) and the other one is transcription factors (TFs), the molecules in regulation of gene expression through binding to either promoter or enhancer region of a gene.

TEs, also known as transposons, are mobile genetic elements that enlarge prokaryotic and eukaryotic genomes (Wicker et al., 2007). McClintock (1950) initially cited the TEs as "controlling elements" because of their capability in effecting expression of nearby genes. Allelic variation for insertions of the transposable elements associated with stress-responsive expression can contribute to variation in the regulation of nearby genes. So novel insertions of transposable elements provide a potential mechanism for genes to obtain cis-regulatory impacts that could contribute to heritable variation for stress response. Since the discovery of TEs by Barbara McClintock in maize (McClintock, 1950) the origins, roles, and regulation of TEs have been subject to enormous interest (Biémont, 2010). Several studies have identified the molecular mechanism that causes the activation of TEs under stress. Stresses and environmental challenges, in particular, are known to stimulate the expression or the transposition of mobile elements in yeast (Rofte et al., 1986; Paguin and Williamson, 1988), animal (Strand and McDonald, 1985; Junakovic et al., 1988) and plant systems in old times (Walbot, 1992; Grandbastien et al., 1997; Cowley and Oakey, 2013). The mobilization of a transposable element or its transcriptional activation might thus represent a good indicator of the host response to stress and some TEs show as stressresponsive transcriptions (Hollister and Gaut, 2009; Ito et al., 2011). For example, expression of the tobacco Tnt1 genetic element can be triggered through biotic and abiotic stresses (Beguiristain et al., 2001). Mao et al. (2015) reported that miniature inverted-repeat transposable element (MITE) inserted in the promoter of a NAC gene (ZmNAC111) is significantly associated with natural variation in maize drought tolerance and this MITE insertion provides insight into the genetic basis for natural variation in maize drought tolerance. In rice (Oryza sativa L.) DNA transposon mPing some cases resulted in up-regulation of genes in response to cold or salt stress (Yasuda et al., 2013). In Arabidopsis the ONSEN retrotransposon activated transcriptionally by heat stress (Ito et al., 2013).

Transcription of these stress-responsive genes is largely controlled by transcription factors (TFs). 
To adapt to such environmental conditions, complex response mechanisms have been evolved in plants, including transcriptional regulation networks for the transduction of stress signals. The implementation of these intricate networks depends on the participation of various TFs (Qin et al., 2011). A number of transcription factors have been identified in the past few years that have been demonstrated to play an essential role in regulating plant responses to stresses (Singh et al., 2002; Hirayama and Shinozaki, 2010). For example, osmotic stress activates several transcription factors, including NAC proteins, which activate an early response to dehydration1 (ERD1) gene. Several basic leucine zipper (bZIP) proteins have been characterized to be Absisic acid (ABA) responsive element binding protein/Absisic acid response element (ABRE) binding factor ( $A R E B / A B F$ ) that bind to the ABREs and have a pivotal role in $A B A$-dependent gene activation (Choi et al., 2000; Uno et al., 2000; Kang et al., 2002; Tran et al., 2004). Recent studies indicate that molecular dynamics, modular flexibility and posttranslational modifications determine the functional specificity of TFs in environmental adaptation. Function of central regulators such as NAC, WRKY, and zinc finger proteins may be modulated by mechanisms as microRNA (miRNA)- mediated posttranscriptional silencing and reactive oxygen species signaling (Goldack et al., 2011). In this study, a subset of TE and TF families that thought related to drought responsive were defined and evaluated together in potato at tuber bulking stage. As well, sequence of defined TEs and TF genes were exposed to genome-wide transposon homology and annotation. Based on our data, TEs and TF genes can exhibit an essential role in regulation of drought tolerance of potato.

\section{Materials and Methods}

\section{RNA-Seq data use in study}

The Illumina RNA-HiSeq reads sequences were obtained from NCBI Short Read Archive. The untreated-control $(\mathrm{CT})$, drought stress treatment
(DT) and re-watering treatment (RWT) reads sequences were retrieved from NCBI Short Read Achieve (SRA)

database (https://www.ncbi.nlm.nih.gov/sra) under accession number SRX912186, SRX912191 and SRX912192, respectively (Gong et al., 2015). The sequenced read length for forward and reverse sequences of paired-end data is $100 \mathrm{bp}$ in length. All readings were obtained in raw sequence data as ".sra" format and converted to "fastq" format for Illimuna by the NCBI (National Center for Biotechnology Information) SRA Toolkit. Lowquality reads and those containing adapter were removed from raw data using in-house Perl scripts. All subsequent analyses were performed on high-quality clean data. Transcriptome assembly for cleaned data was performed in Trinity with default parameters (Grabherr et al., 2011). For sequence mapping, all clean reads were aligned to the reference database using the SOAPaligner/SOAP2 v2.20 program (Xie et al., 2014).

Identification of TEs and TFs responsive to drought stress

To identify the TEs responsive to drought stress, we used Basic Local Alignment Search Tool (BlastN 2.8.0) to search against all sequences of transposons in Repbase database (version 20160829) by using 1e-10 E-value as a cutoff point. Repbase is known as a worldwide reference standard for annotating the existence of repetitive DNA in genomic data.

To identify TFs families in all sequences, the BLASTx with a 1e-5 E-value as a cutoff point against Plant Transcription Factor Database (PlantTFDB;

http://plntfdb.bio.unipotsdam.de/v3.0/download s.php). Moreover, the identified TF reads of each sample were mapped to reference file using Bowtie (Langmead and Salzberg, 2012), redundant sequences were removed on the basis of their chromosome locations and sequence similarity. 


\section{Results and Discussion}

Transposable elements are a major component of many eukaryotic genomes, and constitute the majority of plant nuclear DNA. Previous studies in several plant species have suggested that at least some families of transposable elements may become transcriptionally activated following environmental stress (Makarevitch et al., 2015). In this present study in silico identification of TEs were performed in transcriptome libraries of control, drought treated and rewatered potato plants. Read numbers of TEs in CT, DT and RWT libraries were 44.794, 54.419 and 45.587, respectively (Figure 1 ).

When read numbers of TEs were taken into account it can be said that TEs expressed higher in drought and re-watering treatment samples than control samples. The read numbers for TE subfamilies yielded different distributions between DNA and RNA transposons. A slight reduction was observed in the read numbers of RNA TEs such as Gypsy, Copia and LTR, TEs after re-watering treatments, comparing to control. Interestingly, EnSpm, hAT and Harbinger showed incremental ratios after drought stress treatment while re-watering treatments revealed a declined pattern in addition (Figure 1). Also retrotransposon LINE families showed significant transcription activity in DT and RWT libraries. Mariner families showed no significant transcription activity while SINE and MuDR families showed lower transcriptionally activity under drought conditions. These results supported that genome and transcriptome orientation by transposon activity might have a role in adaptation and regulation of stress response (Negi et al., 2016).

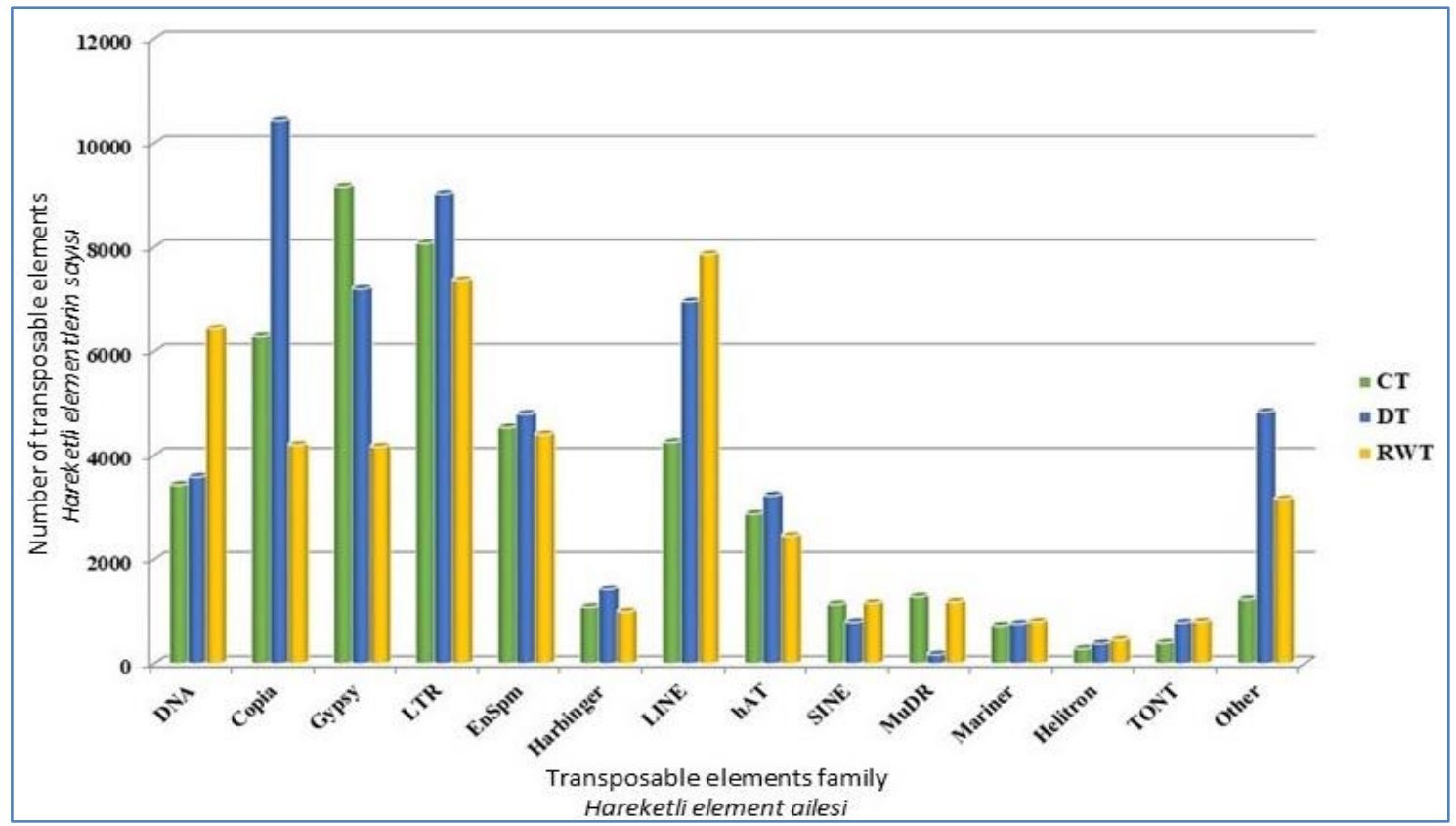

Figure 1. The numbers of DNA and RNA transposons obtained from RNA-seq libraries of CT, DT and RWT samples Şekil 1. CT, DT ve RWT örneklerinin RNA-seq kütüphanelerine ait DNA ve RNA transpozonlarının sayısı

Besides, regulation of epigenetic mechanisms has an impact on transcriptional activity of TEs in the water deficit (Makarevitch et al., 2015). Although DNA transposon's transcription activity is controlled strongly, several retrotransposons become transcriptionally active under some stresses like drought stress, wounding or other abiotic stresses (Grandbastien, 1997; Takeda et al., 1998; Capy et al., 2000). But in this current study, it was observed that RNA transposons more active than DNA transposons. In addition retrotransposon classes such as Copia and Gypsy might play an active role in $S$. tuberosum metabolism since plenty of transcript encoding them was identified in the libraries (Figure 1).

Various genes that function as stress sensors in signaling transduction pathways, which comprise a network of protein-protein reactions, TFs and 
promoters, are activated in plants under stress conditions (Mahajan and Tuteja, 2005). TFs are the main components to understand the complexity of expression of stress induced genes in their signaling network as suggested in various studies (Agarwal et al., 2006; Rue et al., 2008; Ranjan et al., 2012). To assess the complex network of signaling pathways in drought stress, we further compared the profiles of the TFs in control, drought treated and rewaterd potato plants. The read numbers of TFs in CT, DT and RWT libraries were 54.186, 68.788 and 61.017, respectively (Figure 2 ).

bHLH (basic helix-loophelix), AP2/ERF (APETALA2/ethylene response factor), MYB (myeloblastosis protein), WRKY, $\mathrm{C} 2 \mathrm{H} 2$ were the top five families in DT libraries while AP2/ERF, bHLH, MYB, NAC, WRKY were the top five families in RWT libraries.

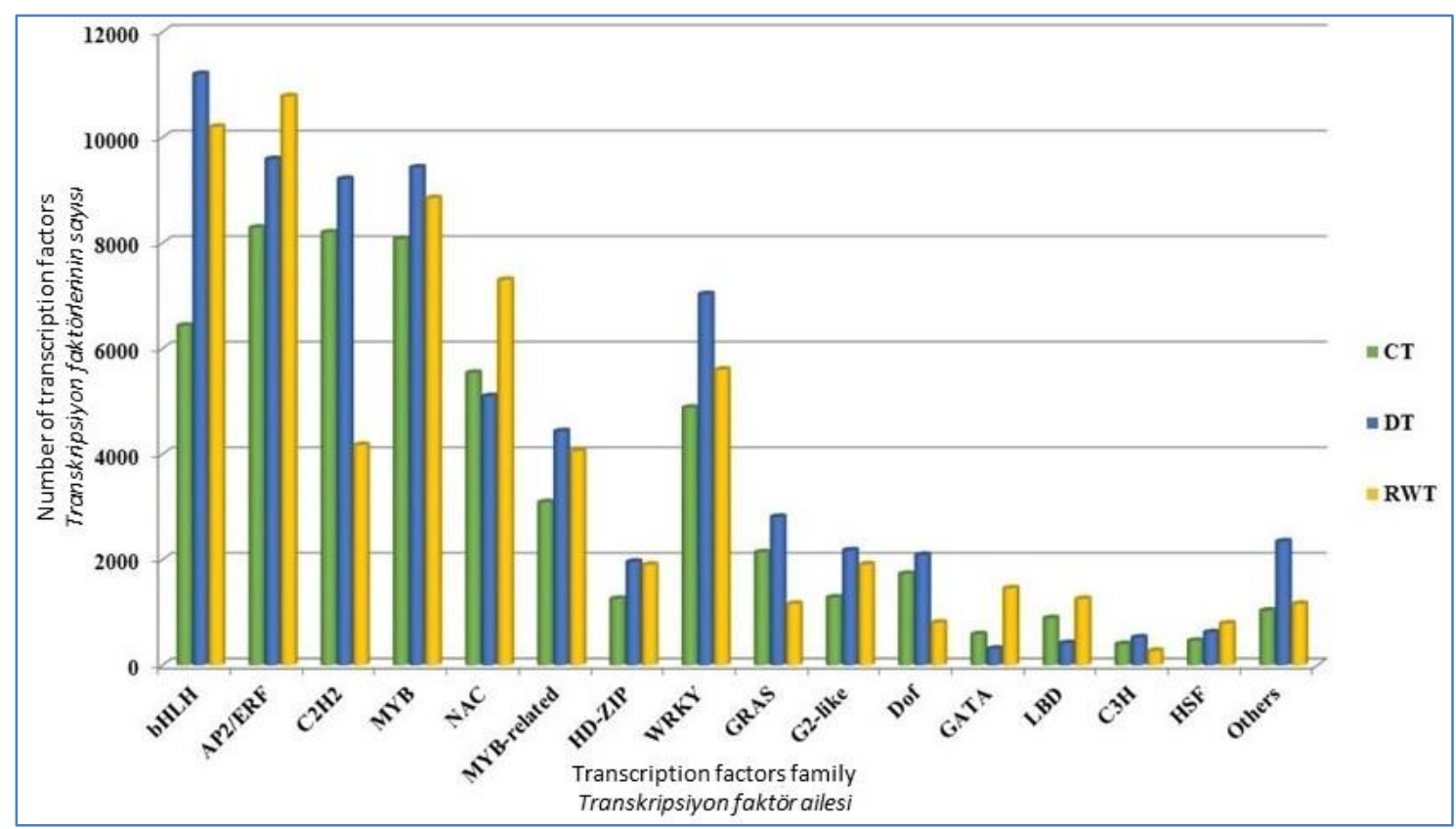

Figure 2. The numbers of transcription factors obtained from RNA-seq libraries of CT, DT and RWT samples Şekil 2. CT, DT ve RWT örneklerinin RNA-seq kütüphanelerine ait transkripsiyon faktörlerin sayısı

So, many TFs, such as AP2/ERF, MYB, WRKY and $\mathrm{bHLH}$, act as key regulators in signal transduction pathways involved in plant response to drought stress (Shinozaki, and YamaguchiShinozaki, 2007; Goldack et al., 2011). Consistently, we observed four TF-encoding genes, WRKY, bHLH, AP2/ERF and MYB, which came into prominence under drought stress and re-watering conditions. In particular, genes encoding WRKY, bHLH, and ERF showed expression alterations under either condition, indicating that TF-encoding genes may have important functions in regulating the response to drought stress and re-watering stimulus in potato. These results were supported by previous studies indicating TFs have a important role in response to drought stress in potato (Schafleitner et al., 2007; Singh et al., 2013; Charfeddine et al., 2015).
Singh et al. (2013), reported that, StNAC genes have an important role in tissue spesific drought stress of Solanum tuberosum L. Also, StERF genes are involved in different stress response pathways in potato, and then these genes expression showed diverse expression profiles, suggesting that they are related to different signaling pathways in the different organs and during different stresses (Charfeddine et al., 2015). In addition, four groups of TFs, MYB-related, HD-ZIP, G2-like and HSF, were up-regulated in drought and re-watering treatments. Moreover, five groups of TFs, GRAS, C3H, LBD, Dof and GATA, exhibited converse expressions between DT and RWT libraries (Figure 2). Several reports have shown that TF families in response drought stress have a role in stress adaptation of the plants (Govind et al., 2009; Gong et al., 2010; Meng et 
al., 2010). Our results underlines the role of the TFs in dynamic network center as well as interaction and competition of pathways exhibit complexity of molecular links in stress adaptation.

\section{Conclusion}

In this present study, TE families and TFs were profiled to understand the molecular mechanisms occurred during the drought and re-watering stress. As a result of that study it was observed that water deficit affected the transcriptional activity of several transposons. The analysis of TEs will provide useful information about mobility genetic elements roles in potato under the drought stress. This study is also valuable for the further researches of TE-mediated gene mutation and contributes to elucidating the roles of TEs in plant genome evolution. Identification of TEs and TFs which are taking part in stress can offer useful information for functional genomics and designing novel breeding strategies in developing stress tolerant plants.

\section{References}

Agarwal, P.K., Agarwal, P., Reddy, M.K. \& Sopory, S.K. (2006). Role of DREB transcription factors in abiotic and biotic stress tolerance in plants. Plant Cell Reports, 25(12): 1263-1274.

Beguiristain, T., Grandbastien, M.A., Puigdomènech, P. \& Casacuberta, J.M. (2001). Three Tnt1 subfamilies show different stress-associated patterns of expression in tobacco. Consequences for retrotransposon control and evolution in plants. Plant Physiology, 127(1): 212-221.

Biémont, C. (2010). A brief history of the status of transposable elements: from junk DNA to major players in evolution. Genetics, 186(4): 1085-1093.

Capy, P., Gasperi, G., Biémont, C. \& Bazin, C. (2000). Stress and transposable elements: co-evolution or useful parasites? Heredity, 85(2): 101-106.

Charfeddine, M., Saidi, M.N., Charfeddine, S., Hammami, A. \& Bouzid, R.G. (2015). Genome-Wide Analysis and Expression Profiling of the ERF Transcription Factor Family in Potato (Solanum tuberosum L.). Molecular Biotechnology, 57(4): 348-358.

Choi, H., Hong, J., Ha, J., Kang, J. \& Kim, S.Y. (2000). ABFs, a family of ABA-responsive element binding factors. Journal of Biological Chemistry, 275(3): 1723-1730.

Cowley, M. \& Oakey, R.J. (2013). Transposable elements rewire and fine-tune the transcriptome. PLoS Genetics, 9(1): 1-7.

Draffehn, A.M., Meller, S., Li, L. \& Gebhardt, C. (2010).
Natural diversity of potato (Solanum tuberosum) invertases. BMC Plant Biology, 10(271): 2-15.

FAOSTAT, (2018). The Statistics Division of the FAO. Retrieved from: http://www.fao.org/faostat/en/data.

Felcher, K.J., Coombs, J.J., Massa, A.N., Hansey, C.N., Hamilton, J.P., Veilleux, R.E., Buell, C.R. \& Douches, D.S. (2012). Integration of Two Diploid Potato Linkage Maps with the Potato Genome Sequence. PLOS ONE, 7(4): 1-11.

Golldack, D., Lüking, I. \& Yang, O. (2011). Plant tolerance to drought and salinity: stress regulating transcription factors and their functional significance in the cellular transcriptional network. Plant Cell Reports, 30(8): 1383-1391.

Gong, P., Zhang, J., Li, H., Yang, C., Zhang, C., Zhang, X., Khurram, Z., Zhang, Y, Wang, T., Fei, Z. \& Ye, Z. (2010). Transcriptional profiles of droughtresponsive genes in modulating transcription signal transduction, and biochemical pathways in tomato. Journal Experimental Botany, 61(13): 3563-3575.

Gong, L., Zhang, H., Gan, X., Zhang, L., Chen, Y., Nie, F., Shi, L., Li, M., Guo, Z., Zhang, G. \& Song, Y. (2015). Transcriptome Profiling of the Potato (Solanum tuberosum L.) Plant under Drought Stress and Water-Stimulus Conditions. PLOS ONE, 10(5): 1-20.

Govind, G., Harshavardhan, V.T., Patricia, J.K., Dhanalakshmi, R., Senthil Kumar, M., Sreenivasulu, N. \& Udayakumar, M. (2009). Identification and functional validation of a unique set of drought induced genes preferentially expressed in response to gradual water stress in peanut. Molecular Genetics and Genomics, 281(6): 591-605.

Grabherr, M.G., Haas, B.J., Yassour, M., Levin, J.Z., Thompson, D.A., Amit, I., Adiconis, X., Fan, L., Raychowdhury, R., Zeng, Q., Chen, Z., Mauceli, E., Hacohen, N., Gnirke, A., Rhind, N., di Palma, F., Birren, B.W., Nusbaum, C., Lindblad-Toh, K. \& Regev, A. (2011). Full-length transcriptome assembly from RNA-Seq data without a reference genome. Nature Biotechnology, 29(7): 644-652.

Grandbastien, M.A., Lucas, H., More, J.B., Mhiri, C., Vernhettes, S. \& Casacuberta, J.M. (1997). The expression of the tobacco Tnt1 is linked to the plant defence responses. Genetica, 100(1): 241-252.

Hirayama, T. \& Shinozaki, K. (2010). Research on plant abiotic stress responses in the post-genome era: past, present and future. Plant Journal, 61(6): 10411052.

Hollister, J.D. \& Gaut, B.S. (2009). Epigenetic silencing of transposable elements: a trade-off between reduced transposition and deleterious effects on neighboring gene expression. Genome Research, 19(8): 4191428.

Ito, H., Gaubert, H., Bucher, E., Mirouze, M., Vaillant, I. \& Paszkowski, J. (2011). An siRNA pathway prevents transgenerational retrotransposition in plants subjected to stress. Nature, 472(7341): 115-119.

Ito, H., Yoshida, T., Tsukahara, S. \& Kawabe, A. (2013). Evolution of the ONSEN retrotransposon family activated upon heat stress in Brassicaceae. Gene, 518(2): 256-261.

Junakovic, N., Di Franco, C., Best-Belpomme, M. \& Echalier, G. (1988). On the transposition of copia-like nomadic 
elements in cultured Drosophila cells. Chromosoma, 97(3): 212-218.

Kang, J.Y., Choi, H.I., Im, M.Y. \& Kim, S.Y. (2002). Arabidopsis basic leucine zipper proteins that mediate stressresponsive abscisic acid signaling. The Plant Cell, 14(2): 343-357.

Langmead, B. \& Salzberg, S.L. (2012). Fast gapped-read alignment with Bowtie 2. Nature Methods, 9(4): 357359.

Lisch, D. (2013). How important are transposons for plant evolution? Nature Reviews Genetics, 14(1): 9-61.

Mahajan, S. \& Tuteja, N. (2005). Cold, salinity and drought stresses: An overview. Archieves Biochemistry and Biophysics, 444(2): 139-158.

Makarevitch, I., Waters, A.J., West, P.T., Stitzer, M. \& Hirsch, C.N., Ross-lbarra, J., Springer, N.M. (2015). Transposable Elements Contribute to Activation of Maize Genes in Response to Abiotic Stress. PLoS Genetics, 11(10): 1-12.

Mao, H., Wang, H., Liu, S., Li, Z., Yang, X., Yan, J., Li, J., Tran, L.S.P. \& Qin, F,A. (2015). transposable element in a NAC gene is associated with drought tolerance in maize seedlings. Nature Communications, 6(8326): 113.

McClintock, B. (1950). The origin and behavior of mutable loci in maize. Proceedings of the National Academy of Sciences, 36(6): 344-355.

Meng, X., Li, F., Liu, C., Zhang, C., Wu, Z. \& Chen, Y. (2010). Isolation and characterization of an ERF transcription factor gene from cotton (Gossypium barbadense L.). Plant Molecular Biology Reporter, 28(3): 176-183.

Negi, P., Rai, A.N. \& Suprasanna, P. (2016). Moving through the Stressed Genome: Emerging Regulatory Roles for Transposons in Plant Stress Response. Frontiers in Plant Science, 7(1448): 1-20.

Paquin, C.E. \& Williamson, V.M. (1988). Effect of temperature on Ty transposition. In: Lambert ME, McDonald JF, Weinstein IB (eds) Eukaryotic Transposable Element as Mutagenic Agents. Cold Spring Harbor Press, NY, 235-244pp.

Qin, F., Shinozaki, K. \& Yamaguchi-Shinozaki, K. (2011). Achievements and challenges in understanding plant abiotic stress responses and tolerance. Plant Cell Physiology, 52(9): 1569-1582.

Ranjan, A., Nigam, D., Asif, M.H., Singh, R., Ranjan S., Mantri, S., Pandey, N., Trivedi, I., Rai, K.M., Jena, S.N., Koul, B., Tuli, R., Pathre, U.V. \& Sawant, S.V. (2012). Genome wide expression profiling of two accession of $G$. herbaceum $L$. in response to drought. BMC Genomics, 13(94): 1-18.

Rofte, M., Spanos, A. \& Banks, G. (1986). Induction of yeast Ty element transcription by ultraviolet light. Nature, 319(1): 339-340.

Schafleitner, R., Gutierrez, R., Espino, R., Gaudin, A., Pérez, J., Martínez, M., Domínguez, A., Tincopa, L., Alvarado, C., Numberto, G. \& Bonierbale, M. (2007). Field Screening for Variation of Drought Tolerance in Solanum tuberosum L. by Agronomical, Physiological and Genetic Analysis. Potato Research, 50(1): 71-85.

Shinozaki, K. \& Yamaguchi-Shinozaki, K. (2007). Gene networks involved in drought stress response and tolerance. Journal Experimental Botany, 58(2): 221227.
Singh, K.B., Foley, R.C. \& Onate-Sanchez, L. (2002). Transcription factors in plant defense and stress responses. Current Opinion in Plant Biology, 5(5): 430-436.

Singh, A.K., Sharma, Pal, A.K., Acharya, V. \& Ahuja, P.S. (2013). Genome-Wide Organization and Expression Profiling of the NAC Transcription Factor Family in Potato (Solanum tuberosum L.). DNA Research, 20(4): 403-423.

Strand, D.J. \& McDonald, J.F. (1985). Copia is transcriptionally responsive to environmental stress. Nucleic Acids Research, 13(12): 4401-4410.

Takeda, S., Sugimoto, K., Otsuki, H. \& Hirochika, H. (1998). Transcriptional activation of the tobacco retrotransposon Tto1 by wounding and methyl jasmonate. Plant Molecular Biology, 36(3): 365-376.

Tran, L.S.P., Nakashima, K., Sakuma, Y., Simpson, S.D., Fujita, Y., Maruyama, K., Fujita, M., Seki, M., Shinozaki, K. \& Yamaguchi-Shinozaki, K. (2004). Isolation and functional analysis of Arabidopsis stress-inducible NAC transcription factors that bind to a drought-responsive cis-element in the early responsive to dehydration stress 1 promoter. The Plant Cell, 16(9): 2481, 2498.

Tripathi, P., Rabara, R.C. \& Rushton, P.J. (2014). A systems biology perspective on the role of WRKY transcription factors in drought responses in plants. Planta, 239(2): 255-266.

Uno, Y., Furihata, T., Abe, H., Yoshida, R., Shinozaki, K. \& Yamaguchi-Shinozaki, K. (2000). Arabidopsis basic leucine zipper transcription factors involved in an abscisic acid-dependent signal transduction pathway under drought and highsalinity conditions. Proceedings of the National Academy of Sciences of the United States of America, 97(21): 11632-11637.

Walbot, V. (1992). Reactivation of Mutator transposable element of maize by Itraviolet light. Molecular and General Genetics, 234(3), 353-360.

Wicker, T., Sabot, F., Hua-Van, A., Bennetzen, J.L., Capy, P., Chalhoub, B., Flavell, A., Leroy, P., Morgante, M., Panaud, O., Paux, E., SanMiguel, P. \& Schulman, A.H. (2007). A unified classification system for eukaryotic transposable elements, Nature Review Genetics, 8(1): 973-982.

Wu, S., Hu, C., Tan, Q., Nie, Z. \& Sun, X. (2014). Effects of molybdenum on water utilization, antioxidative defense system and osmoticadjustment ability in winter wheat (Triticum aestivum) under drought stress. Plant Physiology and Biochemistry, 83(2014): 365-374.

Xie, Y., Wu, G., Tang, J., Luo, R., Patterson, J., Liu, S. \& Wang, J. (2014). SOAPdenovo-Trans: de novo transcriptome assembly with short RNA-Seq reads. Bioinformatics, 30(12): 1660-1666.

Yasuda, K., Ito, M., Sugita, T., Tsukiyama, T., Saito, H., Naito, K., Teraishi, M., Tanisaka, T. \& Okumoto, Y. (2013). Utilization of transposable element mPing as a novel genetic tool for modification of the stress response in rice. Molecular Breeding, 32(3): 505-516.

Yue, G., Zhuang, Y., Li, Z., Sun, L. \& Zhang, J. (2008). Differential gene expression analysis of maize leaf at heading stage in response to water-deficit stress. Bioscience Reports, 28(3): 125-134. 